\title{
In vitro synergistic antitumor activity of a combination of 5-fluorouracil and irinotecan in human colon cancer
}

\author{
YASUHIRO INOUE, KOJI TANAKA, JUNICHIRO HIRO, SHIGEYUKI YOSHIYAMA, \\ YUJI TOIYAMA, TOMOYA EGUCHI, CHIKAO MIKI and MASATO KUSUNOKI \\ Department of Gastrointestinal and Pediatric Surgery, Division of Reparative Medicine, \\ Institute of Life Sciences, Mie University Graduate School of Medicine, Mie, Japan
}

Received August 29, 2005; Accepted October 13, 2005

\begin{abstract}
The combination of irinotecan and a fluoropyrimidine is widely accepted as a treatment for advanced colorectal cancer. However, evaluable data on the feasibility of these combinations has not been presented, and an optimal sequence for administration has not been experimentally and clinically determined. The sequential effect of a combination of 5-FU and CPT-11 in the human colon cancer cell line LoVo was evaluated by WST-8 colorimetric assay. The cytotoxicy and cell cycle distributions of each drug were analyzed by apoptosis assay and flow cytometry. Further, the potential mechanisms of the sequence-dependent effects were investigated by a microarray technique, and confirmed by Western blot analysis. The cytotoxicity of 5-FU (10, 100, $1000 \mu \mathrm{M})$ followed by CPT-11 $(1 \mu \mathrm{M})$ was significantly greater than that of CPT-11 $(1 \mu \mathrm{M})$ followed by 5 -FU $(10$, $100,1000 \mu \mathrm{M})(\mathrm{p}<0.05)$. In cell cycle distribution, 5-FU exposure for $24 \mathrm{~h}$ increased the $\mathrm{S}$ phase fraction in a dosedependent manner; though there was no significant difference in cell cycle distribution in $24 \mathrm{~h} \mathrm{CPT}-11(0.01-1 \mu \mathrm{M})$ exposure. Microarray analysis revealed that expressions of some apoptosis related genes such as Bcl-2 changed, and were correlated with sequence-dependent cytotoxicity of the $5-\mathrm{FU} \rightarrow \mathrm{CPT}-11$ sequence. Western blot analysis confirmed that the $\mathrm{Bcl}-2 / \mathrm{Bax}$ ratio was lower after $5-\mathrm{FU} \rightarrow \mathrm{CPT}-11$ sequence than before. The sequence-dependent cytotoxic effect may depend on the sensitizing effect of 5-FU pretreatment on CPT-11 cytotoxicity. 5-FU followed by CPT-11 administration may be an optimal sequence for IFL treatment of advanced colon cancer.
\end{abstract}

\section{Introduction}

Since randomized trials showed an increase in the response rate and a modest increase in survival when irinotecan (CPT-11)

Correspondence to: Dr Masato Kusunoki, Department of Gastrointestinal and Pediatric Surgery, Division of Reparative Medicine, Institute of Life Sciences, Mie University Graduate School of Medicine, 2-174 Edobashi, Tsu, Mie 514-8507, Japan

E-mail: kusunoki@clin.medic.mie-u.ac.jp

Key words: synergistic antitumor activity, 5-fluorouracil, irinotecan, colon cancer was added to 5-fluorouracil (5-FU) and leucovorin (LV) $(1,2)$, the combination of these agents (IFL) has become a widely accepted treatment for patients with advanced colorectal cancer. However, no evaluable data on the feasibility of these combinations has been presented. In the United States, IFL consisting of bolus 5-FU and LV in combination with $90 \mathrm{~min}$ infused CPT-11, as reported by Saltz et al, has been widely used as a standard treatment for metastatic colorectal cancer (CRC) (1). By contrast, infused 5-FU, instead of bolus 5-FU injection, has been used in the European IFL regimen (2). However, toxicity and treatment related deaths of IFL are reported to be higher than that of the 5-FU/LV combination $(3,4)$. Although modifying dose, duration, and administration for IFL has been attempted to decrease toxicity and the death rate, an optimal administration sequence for these agents remains uncertain (5-8). Experimental studies to determine an optimal sequence of drug administration were also inconclusive, and most reports have favored a sequence in which CPT-11 was given before 5-FU (9-12). Other reports have shown that the reverse sequence was equally as effective $(13,14)$.

In Japan, our pharmacokinetic modulating chemotherapy (PMC), which has a low toxicity rate, has also proven highly effective in treating colorectal cancer (15-17). PMC consists of a continuous i.v. infusion of 5-FU over $24 \mathrm{~h}$ for 1 day a week at $600 \mathrm{mg} / \mathrm{m}^{2} /$ day, and an oral dose of uracil-tegafur (UFT), a 5-FU derivative, at $400 \mathrm{mg} /$ day for 5-7 days per week, repeated every week. A recent in vitro study at our institute showed that the PMC regimen targets at least two different phases of the cell cycle (18). These two pathways depend on the integrity of the schedule oriented cell cycle check points; G2-M arrest and mitotic catastrophe at lower 5-FU, and G1-S arrest and apoptosis at higher 5-FU. This may be the reason why PMC is one of the more effective regimens against colorectal cancer among the various 5-FU-based chemotherapies (19). Theoretically, we consider the combination of CPT-11, $\mathrm{LV}$ and PMC to be the most aggressive front-line treatment for advanced colorectal cancer since the activity of CPT-11 is very schedule-dependent and S-phase-specific (20). From a sequential viewpoint, the dual antitumor effect of 5 -FU by prior PMC treatment may enhance the subsequent effect of CPT-11. Indeed, we instigated dose intensification of CPT-11 for unresectable colorectal cancer, and found a marked response and a manageable level of toxicity in this modification of PMC. 
The present study aimed to clinically evaluate the role of the administration sequence of the combination of 5-FU with CPT-11 in human colon cancer. For this we used a fixed dose of CPT-11 (at a clinically relevant drug concentration) with varying doses of 5-FU (PMC therapeutic range). We focused on p53-dependent apoptosis and used the colon cancer cell line LoVo (wild-type p53), since in a previous study we found dual antitumor effect of 5-FU regardless of mutations in p53 gene (18). Additionally, we investigated genes associated with sequence-dependent cytotoxicity using a DNA microarray to clarify the biochemical mechanism of the synergistic interaction.

Cell lines and culture conditions. The human colon cancer cell line LoVo was obtained from the Cell Resource Center for Biomedical Research, Institute of Development, Aging and Cancer, Tohoku University (Miyagi, Japan). LoVo cells were grown in monolayer culture in RPMI-1640 (SigmaAldrich, Inc., St. Louis, MO. USA) supplemented with fetal bovine serum [FBS, 10\% (v/v), Gibco BRL, Tokyo, Japan], glutamine $(2 \mathrm{mM})$, penicillin (100000 units/l), streptomycin $(100 \mathrm{mg} / \mathrm{l})$, and gentamycin $(40 \mathrm{mg} / \mathrm{l})$ at $37^{\circ} \mathrm{C}$ in a $5 \% \mathrm{CO}_{2}$ environment. For routine passage, cultures were spilt 1:10 when they reached $90 \%$ confluence, generally every 3 days. For all experiments, cells at the fifth to ninth passage were used. All experiments were performed with exponentially growing cells.

Anticancer agents. 5-fluorouracil was obtained from Sigma Aldrich and reconstructed in distilled water. Irinoteacan was purchased from Toronto Research Chemicals Inc (North York, ON, Canada). These two drugs were dissolved in appropriate concentrations with distilled water and stored at $-20^{\circ} \mathrm{C}$ until used in the experiments.

Concept of the experimental protocol. Although the $\mathrm{IC}_{50}$ value (a drug concentration responsible for $50 \%$ growth inhibition) of each drug was generally used for the combination study, as much as possible we used the concentration of each drug as determined from clinical use. 5-FU concentrations were referenced to our previous reports and to drug information obtained from Kyowa Hakko Kogyo (Tokyo, Japan). Assays of 5-FU plasma concentrations in 23 patients receiving PMC showed serum concentrations of 5-FU ranged from 88 to $1323 \mathrm{ng} / \mathrm{ml}(0.1-10 \mu \mathrm{M})$. Drug information on 5-FU from Kyowa Hakko Kogyo shows that plasma concentration of 5-FU reaches $15.3 \mu \mathrm{g} / \mathrm{ml}(100 \mu \mathrm{M})$ after bolus injection of 5 -FU $500 \mathrm{mg} /$ body, and also reaches $0.6 \mu / \mathrm{ml}(5 \mu \mathrm{M})$ during continuous infusion of 5-FU $60 \mathrm{mg} /$ $\mathrm{kg} / 48 \mathrm{~h}$.

CPT-11 concentrations were also referenced to plasma concentrations obtained from clinical use, as found in information on irinotecan hydrochloride (CPT-11) from Daiichi Pharmaceutical Co., Ltd (Tokyo, Japan), showing that plasma concentrations of CPT-11 reach 0.7-7.1 $\mu \mathrm{g} / \mathrm{ml}(1-10$ $\mu \mathrm{M})$ after drip infusion of CPT-11 $50-350 \mathrm{mg} / \mathrm{m}^{2}$.

Drug concentration, exposure time and administration schedule. We adopted clinically relevant concentrations of 5-FU and CPT-11. Although we should consider the doubling time of LoVo cells and subsequently decide exposure time; for experimental simplicity, we used just the 249-h exposure time for each drug. Final concentrations used ranged from 0.1 to $1000 \mu \mathrm{M}$ for 5 -FU and from 0.01 to $100 \mu \mathrm{M}$ for CPT- 11 .

For the cytotoxicity of each drug, LoVo cells in an exponential growth phase were treated for $24 \mathrm{~h}$ with various concentrations of 5-FU or CPT-11. After discarding media containing each drug and replacing it with fresh media, cytotoxicity was evaluated using WST-8 colorimetric assay. For the combination study, LoVo cells were exposed to the first drug (5-FU or CPT-11) for $24 \mathrm{~h}$. After discarding media containing the first drug and replacing it with fresh media, the second drug was administered and incubated for $24 \mathrm{~h}$. Cytotoxic evaluation was similarly performed. Drug-exposure schedules were determined as follows: i) no treatment; ii) 5-FU alone (0.1, $1,10,100$, and1000 $\mu \mathrm{M}$ for $24 \mathrm{~h})$; iii) CPT-11 alone (0.01, 0.1, $1,10$, and $100 \mu \mathrm{M}$ for $24 \mathrm{~h})$; iv) 5 -FU $(0.1,1,10,100$, and $1000 \mu \mathrm{M}$ for $24 \mathrm{~h}$ ) followed by CPT-11 (1 or $10 \mu \mathrm{M}$ for $24 \mathrm{~h}$ ); v) CPT-11 ( 1 or $10 \mu \mathrm{M}$ for $24 \mathrm{~h}$ ) followed by 5 -FU $(0.1,1$, 10,100 , and $1000 \mu \mathrm{M}$ for $24 \mathrm{~h}$ ). Experiments were done in triplicate for each time point, and averages (means) with standard deviations (S.D.) were calculated.

Growth inhibition assay. The cytotoxicity was evaluated by WST-8 [2-(2-methoxy-4-nitrophenyl)-3-(4-nitrophenyl)-5-(2, 4-disulfophenyl)-2H-tetrazolium, monosodium salt] colorimetric assay. SW480 cells (5000 cells/well) were seeded into 96-well cell plates (Becton Dickinson Labware, NJ, USA) in $100 \mu \mathrm{l}$ of culture medium for $24 \mathrm{~h}$ prior to drug exposure. After 24-h preincubation, cells were treated with various concentrations of 5-FU or CPT-11 for various durations for the different protocols.

After drug exposure for indicated concentrations and hours, the medium was discarded and replaced with $90 \mu 1$ of fresh medium followed by adding $10 \mu \mathrm{l}$ WST- 8 reagent solution (Cell Counting Kit, Dojindo Laboratories, Japan) and incubated for $4 \mathrm{~h}$ at $37^{\circ} \mathrm{C}$ in the incubator.

Cell viability was determined according to colorimetric comparison by reading optical density (OD) values from a microplate reader (SoftMax, Molecular Devices Corporation, CA) at an absorption wavelength of $450 \mathrm{~nm}$. Cytotoxicity was evaluated by a Cell Counting Kit according to manufacturer's instruction.

Apoptosis assay. The Chemicon ssDNA Apoptosis ELISA Kit (Chemicon International, Inc., CA, USA) that detects denatured DNA with monoclonal antibody (mAb) to single-strand DNA (ssDNA) was used according to the manufacturer's instructions. In brief, LoVo cells $\left(5 \times 10^{3}\right.$ per well) were treated with formamide to denature DNA in apoptotic cells and then stained with a mixture of mAb to ssDNA and peroxidase-labeled secondary antibody. Color development was quantified using a Microplate Reader at $405 \mathrm{~nm}$. Comparison of the absorbance of the treated sample with both negative and positive controls determined the extent of ssDNA in apoptotic cells.

Flow cytometric analysis. Cell cycle distribution was determined by DNA content analysis after propidium iodide staining. Cells were treated with various concentrations of each drug for $24 \mathrm{~h}$. They were then harvested, fixed in $70 \%$ ethanol, incubated with $2 \mathrm{mg} / \mathrm{ml} \mathrm{RNase,} \mathrm{and} \mathrm{stained} \mathrm{in}$ 
$50 \mu \mathrm{g} / \mathrm{ml}$ of propidium-iodide solution. The DNA content of approximately $1 \times 10^{5}$ stained cells was analyzed using a FACScan flow cytometer. The fraction of the cells in G0-G1, $\mathrm{S}$, and G2-M phases were analyzed by DNA program software.

Total RNA extraction. Concentrations of 5-FU at 10 or $100 \mu \mathrm{M}$ for $24 \mathrm{~h}$ and CPT-11 at 1 or $10 \mu \mathrm{M}$ for $24 \mathrm{~h}$ were selected for total RNA extraction because combinations using these concentrations showed significant differences in sequencedependent cytotoxicities. LoVo cells (5000) were seeded on plastic tissue culture flasks $\left(75 \mathrm{~cm}^{2}\right)$ in $15 \mathrm{ml}$ of culture medium. After 24- or 48-h preincubation, cells were treated with 5 -FU at 10 or $100 \mu \mathrm{M}$ for $24 \mathrm{~h}$ followed by CPT-11 at 1 or $10 \mu \mathrm{M}$ for $24 \mathrm{~h}(\mathrm{~A})$, and by the reverse sequence (B). Tumor cells were washed with phosphate-buffered saline (PBS) after drug treatment and harvested with trypsin. After that, total RNA was extracted using an RNeasy Midi kit (Qiagen Inc., Chatsworth, CA) according to the manufacturer's instructions.

Microarray analysis. Microarray analyses were performed as previously (21). Concentrations of each total RNA were measured and verified for quality for analysis. A) 5-FU at $10 \mu \mathrm{M}$ for $24 \mathrm{~h}$ followed by CPT-11 at $1 \mu \mathrm{M}$ for $24 \mathrm{~h}$ and the reverse sequence, B) CPT-11 at $1 \mu \mathrm{M}$ for $24 \mathrm{~h}$ followed by 5 -FU at $10 \mu \mathrm{M}$ for $24 \mathrm{~h}$, were selected for microarray analysis. Finally, fluorescent signals were detected on a confocal laser scanner (HB GeneArray Scanner, Affymetrix) and analyzed with the DenasisArray (Hitachi software engineering) and Excel (Microsoft. Redmond, WA). Genes with average intensity ratio that showed a $>2$-fold or 0.5 -fold change were selected. Consequently, selected genes were further analyzed for statistical comparison.

Protein extraction and Western blot analysis. LoVo cells were exposed to combinations of first 5-FU and then CPT-11 for $24 \mathrm{~h}$ each in various administration sequences. After drug treatment, cells were homogenized in lysis buffer (Tris-buffered saline, $\mathrm{pH} 7.5$, containing $1 \%$ Triton $\mathrm{X}-100$ ) for $5 \mathrm{~min}$ on ice. After centrifugation at $15000 \mathrm{rpm}$ for $15 \mathrm{~min}$ at $4^{\circ} \mathrm{C}$, the supernatants were collected and frozen at $-20^{\circ} \mathrm{C}$ until analysis. The protein concentration was measured by BCA protein assay (Pierce, Rockford, IL). Lysates containing $10 \mu \mathrm{g}$ total protein were mixed with an equal volume of $2 \mathrm{X}$ Laemmli loading buffer containing 2-mercaptoethanol and heated at $100^{\circ} \mathrm{C}$ for $5 \mathrm{~min}$. The samples were electrophoretically separated in $12.5 \%$ gradient polyacrylamide gels containing $0.1 \%$ SDS at $25 \mathrm{~mA}$ for $2 \mathrm{~h}$ followed by semi-dry transfer to an Immun-Blot PVDF membrane (Bio-Rad Laboratories, Hercules, CA) at $12 \mathrm{~V}$ for $2 \mathrm{~h}$. The membranes were blocked with 5\% skim milk in Tris-buffered saline, $\mathrm{pH} 7.5$, containing $0.1 \%$ Tween 20 (TBS-T) for $1 \mathrm{~h}$ at room temperature, and then incubated with a primary antibody diluted in TBS-T/5\% skim milk for $1 \mathrm{~h}$ at room temperature. The primary antibodies used were: a mouse monoclonal anti-Bcl-2 antibody (1:250; Santa Cruz Biotechnology, Santa Cruz, CA), and a mouse monoclonal anti-Bax antibody (1:500; Dako Corp., Carpinteria, CA). After 3 washes in TBS-T, the blots were incubated with alkaline phosphatase-conjugated goat anti-mouse IgG (Promega
Corp., Madison, WI, USA) diluted 1:1000 in TBS-T/5\% skim milk for $1 \mathrm{~h}$ at room temperature. Following treatment with an enhanced chemiluminescence detection solution, the blots were exposed to X-ray film for autoradiographic visualization of the bands. The film was scanned and the relative quantities of the protein bands were analyzed by densitometry using CS Analyzer version 2.0 (ATTO Corporation, Japan).

Statistical analysis. Statistical analysis of patient data including various clinicopathological characteristics was performed using analyzing software (Stat View, version 5; Abacus Concepts, Inc., Berkeley, CA). Results are expressed as mean \pm SD (standard deviation). Unpaired Student's t-test and Mann-Whitney U test were used for comparison among unpaired groups. Spearman rank correlations test was done for statistical correlations. $\mathrm{P}$ values $<0.05$ were considered statistically significant.

\section{Results}

Growth inhibition of LoVo cells by 5-FU and CPT-11. The cytotoxic effects of 5-FU and CPT-11 in LoVo cells were assessed after $24 \mathrm{~h}$ drug exposure, followed by WST-8 colorimetric assay. The concentrations of each drug used in this study are based on our previous reports and plasma levels in clinical use. 5-FU and CPT-11 treatment inhibited LoVo cell growth in a dose-dependent manner (Fig. 1). After 24-h exposure, approximately $40-60 \%$ of the growth inhibitory effect was observed after 5-FU treatment ranging from 10 to $1000 \mu \mathrm{M}$ concentrations. For CPT-11 24-h exposure, $10 \mu \mathrm{M}$ and $100 \mu \mathrm{M}$ CPT-11 induced approximately $40 \%$ and $80 \%$ growth inhibition, respectively.

These result indicate that LoVo cells were inhibited at higher levels of 5-FU in PMC (5-FU-based chemotherapy) therapeutic range; $10 \mu \mathrm{M}$, and at the clinically relevant concentration of CPT-11; $1-10 \mu \mathrm{M}$.

Cytotoxic effects of 5-FU and CPT-11 sequence combination. Clinically, 5-FU in the IFL regimen is used as a bolus injection (Saltz regimen) or by continuous infusion (FOLFILI regimen). In contrast, CPT-11 is usually used as a 90 -min infusion. Concentrations of 5-FU have more variations than those of CPT-11 because of the various administration methods. Taking these findings together, CPT-11 was used at a fixed concentration of $1 \mu \mathrm{M}$ (or $10 \mu \mathrm{M}$ ), and 5-FU was used at serial concentrations of $0.1-1000 \mu \mathrm{M}$ for sequential study.

The cytotoxicity of $5-\mathrm{FU}(10,100,1000 \mu \mathrm{M})$ followed by CPT-11 $(1 \mu \mathrm{M})$ was significantly greater than that of CPT-11 $(1 \mu \mathrm{M})$ followed by $5-\mathrm{FU}(10,100,1000 \mu \mathrm{M})$ (respectively, $\mathrm{p}<0.01)$. (Fig. 2) Although 24-h exposure of CPT-11 (1 $\mu \mathrm{M})$ alone induced $10 \%$ growth inhibition in LoVo cells, the growth inhibitions of 5-FU $(10,100$, and $1000 \mu \mathrm{M}$ for $24 \mathrm{~h}) \rightarrow \mathrm{CPT}$ (1 $\mu \mathrm{M}$ for $24 \mathrm{~h}$ ) were $40 \%, 60 \%$, and $80 \%$, respectively. The cytotoxicity of $5-\mathrm{FU} \rightarrow \mathrm{CPT}$ is also greater than serial concentrations of 5-FU alone.

This shows that pretreatment with 5-FU increases the cytotoxic effect of the subsequently administered CPT-11. The cytotoxicity of serial $5-\mathrm{FU} \rightarrow \mathrm{CPT}-11(1 \mu \mathrm{M})$ sequence is almost similar to that of serial 5-FU $\rightarrow$ CPT-11 $(10 \mu \mathrm{M})$, while the other conditions are the same. 

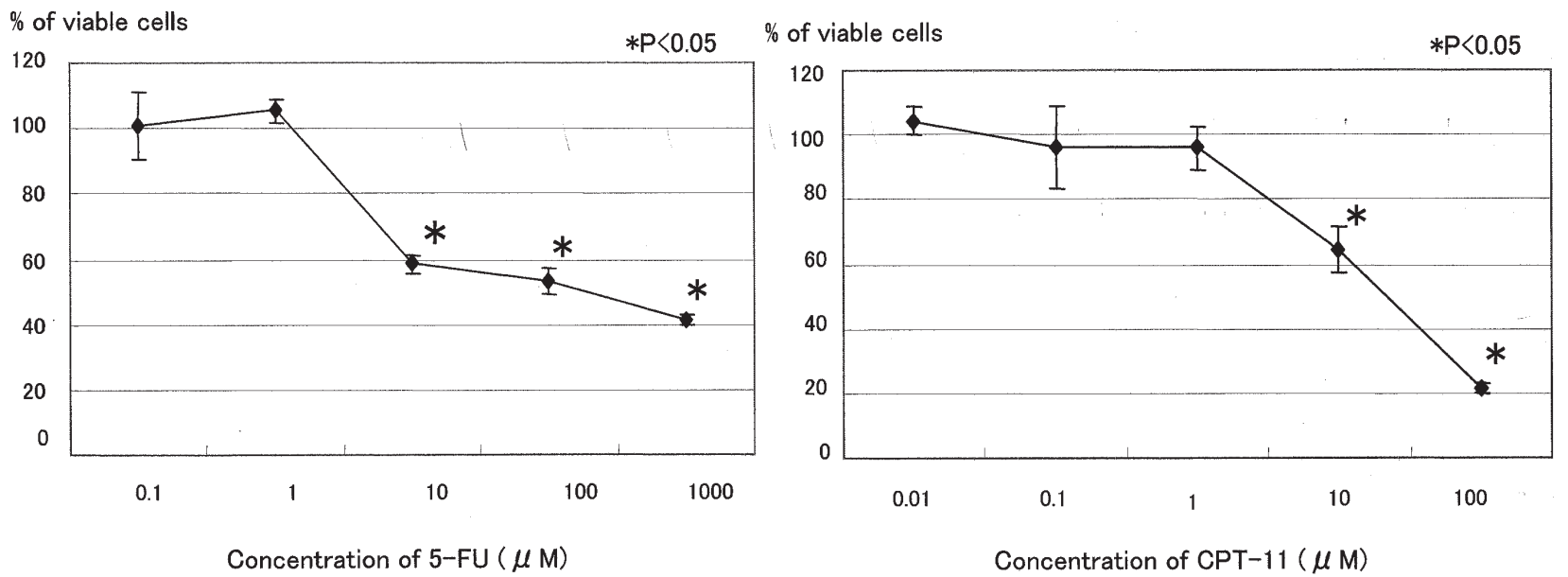

Figure 1. Growth inhibition of LoVo cells by 5-FU and CPT-11. LoVo cells exposed to indicated concentrations of 5-FU or CPT-11 for $24 \mathrm{~h}$. Data represent three separate modified MTT experiments, each done in quadruplicate.

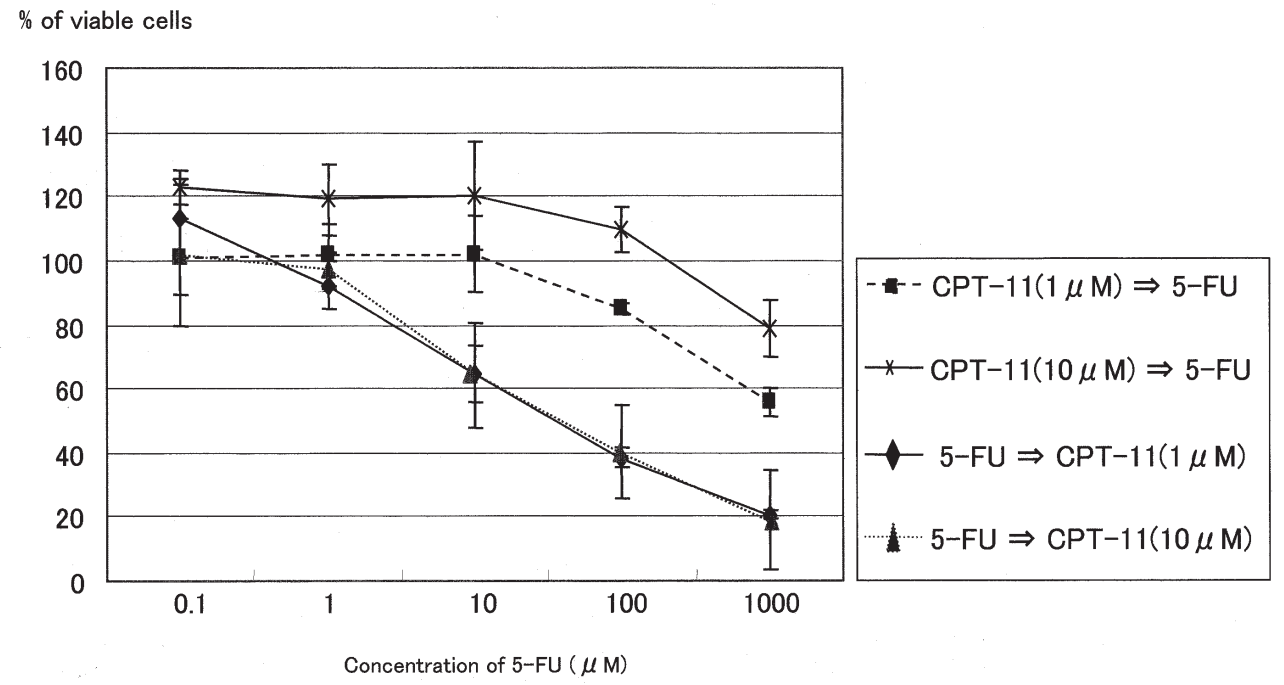

Figure 2. Cytotoxic effects of the combination sequence of 5-FU and CPT-11. 5x $10^{5}$ tumor cells were cultured in 96-well microplates. After $24 \mathrm{~h}$ incubation, cells were exposed to the first drug (5-FU or CPT-11) for $24 \mathrm{~h}$. Thereafter the medium containing the first drug was changed and then tumor cells were treated with the second drug (CPT-11 or 5-FU) for $24 \mathrm{~h}$. Modified MTT assays were performed as described as Materials and methods.

This phenomenon prompted us to consider further study in respect to apoptosis and cell cycle distribution.

Apoptosis in LoVo cells for 5-FU and CPT-11 treatment. As shown in Fig. 3, apoptosis in LoVo cells was slightly induced at the point of 10,100 , and $1000 \mu \mathrm{M} 5$-FU treatment for $24 \mathrm{~h}$. In contrast, apoptosis is significantly induced in just $100 \mu \mathrm{M}$ CPT-11 treatment for $24 \mathrm{~h}$ compared with other concentrations of CPT-11 treatment. Although there were discrepancies in cell death between the cytotoxicity evaluated by WST-8 colorimetric assay and apoptosis evaluated by ssDNA detection kit, this sequential effect may be synergistic, rather than additive for both 5-FU and CPT-11 antitumor effects.

Cell cycle distribution in LoVo for 5-FU and CPT-11 treatment. 5 -FU exposure for $24 \mathrm{~h}$ increased the $\mathrm{S}$ phase fraction in a dose-dependent manner compared with controls. There were no significant differences in cell cycle distribution among the various concentrations (except for 10 and $100 \mu \mathrm{M}$ ) of CPT-11 for $24 \mathrm{~h}$ exposure (Fig. 4). Taken the above findings together, sequence-dependent cytotoxicity may depend on the increase in $\mathrm{S}$ phase fraction due to pretreatment 5-FU because CPT-11 antitumor activity is cell cycle specific, acting more effectively against cancer cells accumulated in $\mathrm{S}$ phase.

Identification of genes correlated with sequence-dependent cytotoxicity of 5-FU and CPT-11. To identify this sequencedependent cytotoxic mechanism, we carried out cDNA-based microarray analysis after treatment of LoVo human colon cancer cells with: a) 5-FU $(10 \mu \mathrm{M})$ followed by CPT-11 $(1 \mu \mathrm{M})$ and b) CPT-11 $(1 \mu \mathrm{M})$ followed by 5-FU $(10 \mu \mathrm{M})$. The exposure time for each drug was $24 \mathrm{~h}$. RNA derived from cells treated with (a) or (b) was reverse transcribed, labeled 


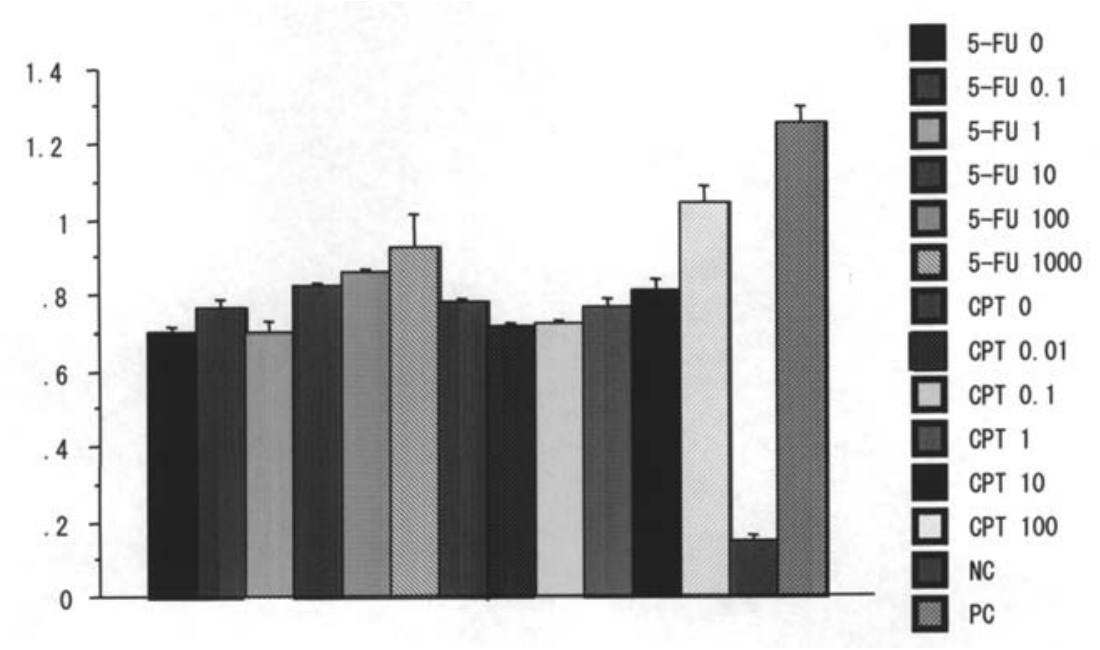

Figure 3. Apoptosis in LoVo cells from 5-FU and CPT-11 treatment. LoVo cells were induced to apoptosis at a significantly higher rate by 5 -FU (1000 $\mu \mathrm{M}$ ) and CPT-11 $(1 \mu \mathrm{M}, 10 \mu \mathrm{M})$ exposure for $24 \mathrm{~h}$ than any other drug exposure pattern.


Figure 4. Cell cycle distribution in LoVo from 5-FU and CPT-11 treatment. There are not significant differences in cell cycle distribution among the various concentrations (except for 10 and $100 \mu \mathrm{M}$ ) of CPT-11 for $24 \mathrm{~h}$ exposure.

and hybridized to a 20000 gene cDNA microarray. Bound cDNA was detected using Cy3 (a) and Cy5 (b) reporter dyes. The expression profiles in the: a) 5 -FU followed by CPT-11 and b) CPT-11 followed by 5-FU were compared and expressed as a Cy3: Cy5 ratio. We found that 22 genes were up-regulated $>2$-fold and 14 genes were down-regulated $<2$-fold (Tables I and II).

Protein level of Bcl-2/Bax ratio by Western blot analysis. To verify the microarray analysis, we carried out Western blot analysis for $\mathrm{Bcl}-2 / \mathrm{Bax}$ expression ratio, and found that the
5 -FU $\rightarrow$ CPT-11 sequence caused the regulation of apoptosis by decreasing the $\mathrm{Bcl}-2 / \mathrm{Bax}$ expression ratio (Fig. 5).

\section{Discussion}

A widely accepted treatment regimen for colorectal cancer has not yet been established from identification of the basic mechanism, but rather by feedback from clinical trials. Various mechanisms have been proposed for combined fluorouracil and CPT-11 chemotherapy, but none alone can explain all of the interactions by clarifying a basic mechanism. 
Table I. Genes down-regulated by the $5-\mathrm{FU} \rightarrow \mathrm{CPT}-11$ sequence.

\begin{tabular}{|c|c|c|}
\hline Accession no. & Gene & Function \\
\hline NM_014736 & KIAA0101 gene product & \\
\hline NM_054012 & Argininosuccinate synthetase & \\
\hline NM_003135 & Ensembl genscan prediction AceGene oligo matches these RefSeq numbers & \\
\hline M13994 & B-cell CLL/lymphoma 2 & Apoptosis \\
\hline XM_027630 & Hypothetical protein xp_027630; loc89959 & \\
\hline NM_001562 & Interleukin 18 (interferon-gamma-inducing factor) & Tumor supressor gene \\
\hline NM_015874 & Recombining binding protein suppressor of hairless (Drosophila) & Apoptosis \\
\hline NM_052837 & Secretory carrier membrane protein 3 & \\
\hline NM_004069 & Adaptor-related protein complex 2 , sigma 1 subunit & \\
\hline NM_014409 & $\begin{array}{l}\text { TAF5-like RNA polymerase II, p300/CBP-associated factor (PCAF)- } \\
\text { associated factor, } 65 \mathrm{kDa}\end{array}$ & Transcription \\
\hline NM_004616 & Transmembrane 4 superfamily member 3 & Oncogene \\
\hline NM_002639 & Serine (or cysteine) proteinase inhibitor, clade B (ovalbumin), member 5 & Oncogene \\
\hline NM_000893 & Kininogen & \\
\hline NM_022802 & C-terminal binding protein 2 & Transcription \\
\hline
\end{tabular}

Table II. Genes up-regulated by the $5-\mathrm{FU} \rightarrow \mathrm{CPT}-11$ sequence.

\begin{tabular}{|c|c|c|}
\hline Accession no. & Gene & Function \\
\hline D38112 & Atpase subunit 6 & \\
\hline AF026246 & herv-e integrase; pol & \\
\hline NM_032036 & tlh29 protein precursor; tlh29 & \\
\hline AF346626 & pr-domain containing protein 17 & Tumor suppressor gene \\
\hline XM_051270 & Hypothetical protein xp_051270; loc93417 & \\
\hline NM_003489 & Receptor interacting protein $140 ;$ nrip1 & Transcription \\
\hline ВC002439 & tat-interacting protein $(30 \mathrm{kDa})$ & \\
\hline XM_018351 & Hypothetical protein xp_018351; loc94852 & \\
\hline XM_006730 & Hypothetical protein xp_006730; itga7 & \\
\hline BC012137 & Similar to syntaxin $5 a$ & \\
\hline XM_037969 & Hypothetical protein dkfzp434n1415; dkfzp434n1415 & \\
\hline NM_005083 & $\begin{array}{l}\text { u2 small nuclear ribonucleoprotein auxiliary factor, small subunit-related } \\
\text { protein } 1 ; \mathrm{u} 2 \mathrm{af} 1 \mathrm{rs} 1\end{array}$ & \\
\hline XM_009179 & xaa-pro dipeptidase; loc126241 & \\
\hline NM_000264 & Patched (drosophila) homolog; ptch & Tumor suppressor gene \\
\hline NM_018457 & dkfzp564j157 protein; dkfzp564j157 & \\
\hline L39610 & $\operatorname{tcrdv} 3 \mathrm{j} 1$ & \\
\hline NM_023068 & Sialoadhesin; sn & Immunology \\
\hline AF044333 & pleiotropic regulator 1; plrg1 & \\
\hline XM_017039 & Hypothetical protein xp_017039; loc95731 & \\
\hline NM_020368 & Disrupter of silencing $10 ;$ sas 10 & \\
\hline NM_000944 & $\begin{array}{l}\text { Protein phosphatase } 3 \text { (formerly } 2 \mathrm{~b} \text { ), catalytic subunit, } \\
\text { alpha isoform (calcineurin a alpha); ppp3ca }\end{array}$ & Apoptosis \\
\hline NM_022773 & Hypothetical protein flj12681; flj12681 & \\
\hline
\end{tabular}





actin

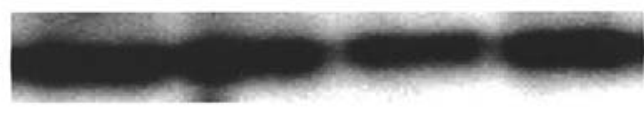

Bcl-2/Bax
ratio

\subsection{1}

1.693

1.207

1 suggesting the $5-\mathrm{FU} \rightarrow \mathrm{CPT}-11$ sequence enhanced subsequent CPT-11 cytotoxicity. In contrast, Pavillard et al reported that cell accumulation in the $\mathrm{S}$ phase fraction by prior CPT-11 treatment enhanced subsequent 5-FU, acting preferentially on the $\mathrm{S}$ phase, indicating the most cytotoxic effect of CPT-11 $\rightarrow 5$-FU (10). These discrepancies may be caused by the differences in cell lines, culture conditions, drug-exposure schedules, cytotoxicity evaluation methods, and the timing of evaluation. In this study, apoptosis of each drug for $24 \mathrm{~h}$ exposure was not significantly different among the various concentrations except for the $100 \mu \mathrm{M} \mathrm{CPT}-11$ treatment. Cell cycle analysis showed that 5-FU exposure for $24 \mathrm{~h}$ increased the $S$ phase fraction in a dose-dependent manner. A possible explanation of sequence-dependent cytotoxicity is that by increasing the $\mathrm{S}$ phase fraction from the pretreatment with $5-\mathrm{FU}$, the $\mathrm{S}$ phase acting drug, CPT-11, may act more effectively against cancer cells. To clarify this potential mechanism, we investigated genes associated with sequencedependent cytotoxicity using a DNA microarray. This study revealed that 22 up-regulated and 14 down-regulated genes correlated with the sequence dependent cytotoxicity of the $5-\mathrm{FU} \rightarrow$ CPT-11 sequence. Of these genes, some have already been shown to be associated with apoptosis. For example, genes showing up-regulated expression included protein phosphatase 3. Protein phosphatase 3 (PPP3, formerly PP2B, Calcineurin), a serine/theronine phosphatase that is tightly regulated by $\mathrm{Ca}^{2+} /$ calmodulin and plays critical roles in many calcium-mediated signal transduction pathways $(25,26)$. Several studies have shown that PPP3 stimulates NF- $\kappa$ B by enhancing inactivation of its inhibitory molecule NF- $\mathrm{KB}$ alpha $(27,28)$. NF-кB is also essential in p53-mediated cell death and induction p53 causes an activation of NF- $\mathrm{BB}$ that correlates with the ability of p53 to induce apoptosis (29). On the other hand, expression of Bcl-2, an anti-apoptotic gene, was down-regulated by $5-\mathrm{FU} \rightarrow \mathrm{CPT}-11$ sequence. To verify the microarray analysis, we next carried out Western blot analysis for the $\mathrm{Bcl}-2 / \mathrm{Bax}$ expression ratio, and found that the 5 -FU $\rightarrow$ CPT-11 sequence caused up-regulation of apoptosis by decreasing the $\mathrm{Bcl}-2 / \mathrm{Bax}$ expression ratio. These results suggested that 5-FU pretreatment like PMC, may play an important role in sensitizing CPT-11 cytotoxicity and so resulting in apoptosis, with p53 dependence.

In conclusion, the cytotoxic effects of the combination of 5-FU and CPT-11 are schedule-dependent in human colon cancer cells. The sequence of $5-\mathrm{FU} \rightarrow \mathrm{CPT}-11$ could be of importance with resultant apoptosis in the treatment of colorectal cancer. Research into an appropriate administration sequence should help us to establish a modifying IFL regimen with less toxicity. To better understand and improve chemotherapy, we need to investigate more deeply the combination of PMC and CPT-11, in both experimental and clinical settings.

\section{References}

1. Saltz LB, Cox JV, Blanke C, et al: Irinotecan plus fluorouracil and leucovorin for metastatic colorectal cancer. Irinotecan Study Group. N Engl J Med 28: 905-914, 2000.

2. Douillard JY, Cunningham D, Roth AD, et al: Irinotecan combined with fluorouracil compared with fluorouracil alone as first-line treatment for metastatic colorectal cancer: a multicentre randomised trial. Lancet 25: 1041-1047, 2000. 
3. Rothenberg ML, Meropol NJ, Poplin EA, van Cutsem E and Wadler S: Mortality associated with irinotecan plus bolus fluorouracil/leucovorin: summary findings of an independent panel. J Clin Oncol 15: 3801-3807, 2001.

4. Sargent DJ, Niedzwiecki D, O'Connell MJ and Schilsky RL: Recommendation for caution with irinotecan, fluorouracil, and leucovorin for colorectal cancer. N Engl J Med 12: 144-145, 2001

5. Ohtsu A, Boku N, Yoshioka T, et al: A Phase II study of irinotecan in combination with 120-h infusion of 5-fluorouracil in patients with metastatic colorectal carcinoma: Japan Clinical Oncology Group Study (JCOG9703). Jpn J Clin Oncol 33: 28-32, 2003.

6. Yalcin S, Oksuzoglu B, Tekuzman G, et al: Biweekly irinotecan plus bolus 5-fluorouracil and folinic acid in patients with advanced stage colorectal cancer. Jpn J Clin Oncol 33: 580-583, 2003.

7. Hwang JJ, Eisenberg SG and Marshall JL: Improving the toxicity of irinotecan/5-FU/leucovorin: a 21-day schedule. Oncology 17: 37-43, 2003.

8. Benson AB III and Goldberg RM: Optimal use of the combination of irinotecan and 5-fluorouracil. Semin Oncol 30: 68-77, 2003.

9. Mans DR, Grivicich I, Peters GJ and Schwartsmann G: Sequencedependent growth inhibition and DNA damage formation by the irinotecan-5-fluorouracil combination in human colon carcinoma cell lines. Eur J Cancer 35: 1851-1861, 1999.

10. Pavillard V, Formento P, Rostagno P, et al: Combination of irinotecan (CPT11) and 5-fluorouracil with an analysis of cellular determinants of drug activity. Biochem Pharmacol 15: 1315-1322, 1998

11. Cao S and Rustum YM: Synergistic antitumor activity of irinotecan in combination with 5-fluorouracil in rats bearing advanced colorectal cancer: role of drug sequence and dose. Cancer Res 15: 3717-3721, 2000.

12. Azrak RG, Cao S, Slocum HK, et al: Therapeutic synergy between irinotecan and 5-fluorouracil against human tumor xenografts. Clin Cancer Res 1: 1121-1129, 2004.

13. Guichard S, Cussac D, Hennebelle I, Bugat R and Canal P: Sequence-dependent activity of the irinotecan-5FU combination in human colon-cancer model HT-29 in vitro and in vivo. Int J Cancer 27: 729-734, 1997.

14. Guichard S, Hennebelle I, Bugat R and Canal P: Cellular interactions of 5-fluorouracil and the camptothecin analogue CPT-11 (irinotecan) in a human colorectal carcinoma cell line. Biochem Pharmacol 1: 667-676, 1998.

15. Kusunoki M, Yanagi H, Kotera H, Noda M and Yamamura T: Effects of pharmacokinetic modulating chemotherapy using oral UFT and continuous venous $5 \mathrm{FU}$ infusion on the prognosis of irradiated rectal carcinomas with p53 overexpression. Int J Oncol 13: 653-657, 1998.
16. Kusunoki M, Yanagi H, Noda $M$ and Yamamura T: The usefulness of pharmacokinetic modulating chemotherapy (UFT plus 5FU) in the treatment of unresectable colorectal carcinomas. Oncol Rep 6: 547-552, 1998.

17. Kusunoki M, Yanagi H, Noda M, Yoshikawa R and Yamamura T: Results of pharmacokinetic modulating chemotherapy in combination with hepatic arterial 5-fluorouracil infusion and oral UFT after resection of hepatic colorectal metastases. Cancer 89: 1228-1235, 2000.

18. Yoshikawa R, Kusunoki M, Yanagi H, et al: Dual antitumor effects of 5-fluorouracil on the cell cycle in colorectal carcinoma cells: a novel target mechanism concept for pharmacokinetic modulating chemotherapy. Cancer Res 1: 1029-1037, 2001.

19. Malet-Martino $\mathrm{M}$ and Martino R: Clinical studies of three oral prodrugs of 5-fluorouracil (capecitabine, UFT, S-1): a review. Oncologist 7: 288-323, 2002.

20. Goldwasser F, Shimizu T, Jackman J, et al: Correlations between S and G2 arrest and the cytotoxicity of camptothecin in human colon carcinoma cells. Cancer Res 56: 4430-4437, 1996.

21. Toiyama Y, Mizoguchi A, Kimura K, et al: Persistence of gene expression changes in noninflamed and inflamed colonic mucosa in ulcerative colitis and their presence in colonic carcinoma. World J Gastroenterol (In press).

22. Inoue $\mathrm{Y}$, Shirane M, Miki C, et al: Gene expression profiles of colorectal carcinoma in response to neo-adjuvant chemotherapy. Int J Oncol 25: 1641-1649, 2004.

23. Saltz LB, Kanowitz J, Kemeny NE, et al: Phase I clinical and pharmacokinetic study of irinotecan, fluorouracil, and leucovorin in patients with advanced solid tumors. J Clin Oncol 14: 2959-2967, 1996.

24. Falcone A, Di Paolo A, Masi G, et al: Sequence effect of irinotecan and fluorouracil treatment on pharmacokinetics and toxicity in chemotherapy-naive metastatic colorectal cancer patients. J Clin Oncol 1: 3456-3462, 2001.

25. Klee CB, Ren H and Wang X: Regulation of the calmodulinstimulated protein phosphatase, calcineurin. J Biol Chem 29: 13367-13370, 1998.

26. Stemmer PM: Interactions of calcineurin A, calcineurin B, and $\mathrm{Ca}^{+}$. Biochemistry 21: 12481-1249, 1999.

27. Frantz B, Nordby EC, Bren GN, et al: Calcineurin acts in synergy with PMA to inactivate kappa/B MAD3, an inhibitor of NF-kappa B. EMBO J 13: 861-870, 1994.

28. Steffan NM, Bren GD, Frantz B, Tocci MJ, O'Neill EA and Paya CV: Regulation of I kappa B alpha phosphorylation by $\mathrm{PKC}$ and $\mathrm{Ca} 2^{+}$-dependent signal transduction pathways. J Immunol 155: 4685-4691, 1995.

29. Ryan KM: Role of NF-kappaB in p53-mediated programmed cell death. Nature 20: 892-897, 2000. 